\title{
Blodtrykk målt med kvikksølvmanometer og med Dinamap under feltforhold - en sammenligning
}

\author{
Per G. Lund-Larsen \\ Statens helseundersøkelser, Postboks 8155 Dep, 0033 Oslo
}

\begin{abstract}
SAMMENDRAG
Blodtrykksmåling med kvikksølvmanometer etter standardiserte prosedyrer, har lenge vært en epidemiologisk referansemetode. Dinamap er en automatisert blodtrykksmåler som måler trykk og hjertefrekvens på grunnlag av oscillometri og moderne elektronikk. Før Statens helseundersøkelser (SHUS) tok i bruk Dinamap på slutten av 80-tallet, ble blodtrykk målt med kvikksølvmetoden (Erkameter) sammenlignet med blodtrykk målt med Dinamap - $\mathrm{i}$ en screening situasjon. Vi fant at Dinamap var et velegnet screeningverktøy. Systolisk blodtrykk ble målt omtrent likt med de to metodene, Dinamap viste seg å måle diastolisk trykk noe lavere enn Erka. Forskjellen Erka-Dinamap avtok med økende målenivå.
\end{abstract}

\section{Lund-Larsen PG. Blood pressure measured with a sphygmomanometer and with Dinamap under field conditions - a comparison. Nor J Epidemiol 1997; 7 (2): 235-241.}

\section{ENGLISH SUMMARY}

Blood pressure measurements with a sphygmomanometer in accordance with standardized methods, has been an epidemiological reference method for a long time. Dinamap is a method of measuring blood pressure automatically, recording both pressure and heart frequency on the basis of oscillometry and modern electronics. Before the National Health Screening Service started using Dinamap, at the end of the eighties, blood pressure was measured with the mercury method (Erkameter) and compared to blood pressures measured with Dinamap - in a screening situation. We then found that Dinamap was a well suited screening tool. Systolic blood pressure measurements were about the same with the two methods, for diastolic pressure Dinamap showed slightly lower values than Erka. The difference Erka-Dinamap diminished at higher measurement levels.

\section{INNLEDNING}

Blodtrykksmåling med kvikksølvmanometer etter standardiserte prosedyrer har lenge vært en epidemiologisk referansemetode. Det meste av det vi vet om befolkningsblodtrykk er basert på blodtrykk målt med kvikksølvmanometer. Utstyret har prinsipielt ikke forandret seg siden Riva-Rocci beskrev palpatorisk måling med dette utstyret i 1896. Korotkoff bidro sterkt til metoden da han i 1905 beskrev måling av både systolisk og diastolisk trykk ved auskultasjon av de såkalte Korotkoff-lydene over en arterie distalt for blodtrykksmansjetten.

\section{FORMÅL}

Det har lenge vært ønskelig med en automatisert BT målemetode der en unngår den menneskelige faktor (bias) ved epidemiologiske målinger. En av de automatiske blodtrykksmålere som lenge har vært i bruk i klinikken, går under betegnelsen DINAMAP 845XT (Critikon). Dette utstyret er basert på oscillometri og moderne elektronikk. Utstyret måler systolisk, diastolisk, middelarterie trykk (MAP) og hjertefrekvens. Dinamap synes ut fra litteraturen å ha bred anvendelse til f.eks. overvåkning av blodtrykk hos barn og voksne, og i forbindelse med kliniske fors $ø$ k. Da Dinamap legger oscillometriske utslag til grunn for beregninger av både trykk og hjertefrekvens, vil det kunne oppstå problemer dersom de oscillometriske utslagene er ujevne enten i frekvens (f.eks. atrieflimmer) eller ved ujevn amplitude (pulsus inequalis).

Vår problemstilling var derfor i første omgang å få tallfestet $\mathrm{i}$ hvilken grad man overhode ville få målt trykk med Dinamap i en befolkningsundersøkelse. Dernest var målsetningen å studere i hvilken grad trykk målt med Dinamap ville avvike fra trykk målt på "gamlemåten" med Erkameter og spesialopplærte sykepleiere. Bakgrunnen for forsøket var om Dinamap var et så egnet epidemiologisk instrument at Statens 
helseundersøkelser kunne gå over til denne målemetoden i sine befolkningsundersøkelser.

\section{METODE}

I forbindelse med Helseundersøkelsen i NordTrøndelag i 1984-86 ble blodtrykket på hele NordTrøndelags befolkning over 19 år målt av 6 spesialtrente sykepleiere etter en standardisert protokoll (Håndbok for hjerte-karundersøkelsene, 40-åringsprosjektet, SHUS 1987) og ved bruk av kvikksølvmanometre (Erkameter). I 1986 ble det i en periode i tillegg til Erkamålingene satt opp en ekstra blodtrykksstasjon med et Dinamap-apparat. Blodtrykket ble først målt etter vanlige rutiner to ganger med ett minutts intervall med Erkameter (mansjetten deflatert i intervallet). En del av de frammøtte ble så spurt om de ville la seg måle en gang til med et annet apparat. Villige med Erkamålt systolisk blodtrykk lik eller under 230 $\mathrm{mmHg}$, ble henvist til Dinamapstasjonen i et annet rom. Her var det lagt opp til en målesituasjon som så langt råd var tilsvarte målesituasjonen som var standard ved Erkamålingene. Den eneste forskjellen i prosedyrene var at man ved Dinamapstasjonen målte og noterte sirkumferensen av høyre overarm $10 \mathrm{~cm}$ ovenfor fossa cubiti og valgte mansjettstørrelse i henhold til dette målet. Ved Erkamålingene brukte man en standardmansjett (tabell 1). Ved Dinamapstasjonen ble blodtrykket målt 4 ganger med 1 minutts mellomrom.

Da man hadde målt 598 individer på denne måten ble det klart at man hadde et alvorlig metodologisk problem (figur 1). Som forventet ser en at blodtrykket gjennomsnittlig faller noen $\mathrm{mm}$ fra første til andre Erkamåling. Verre er det at blodtrykket synes å fortsette å synke slik at det systematisk er lavere eller likt Erka 2 målingen allerede ved første Dinamapmåling. Siden synker trykkene stadig fra første til siste Dinamapmåling. Det syntes vanskelig ved en slik studiedesign å skille et systematisk blodtrykksfall over tid i den målte populasjonen fra en eventuell forskjell forårsaket av forskjellige målemetoder.

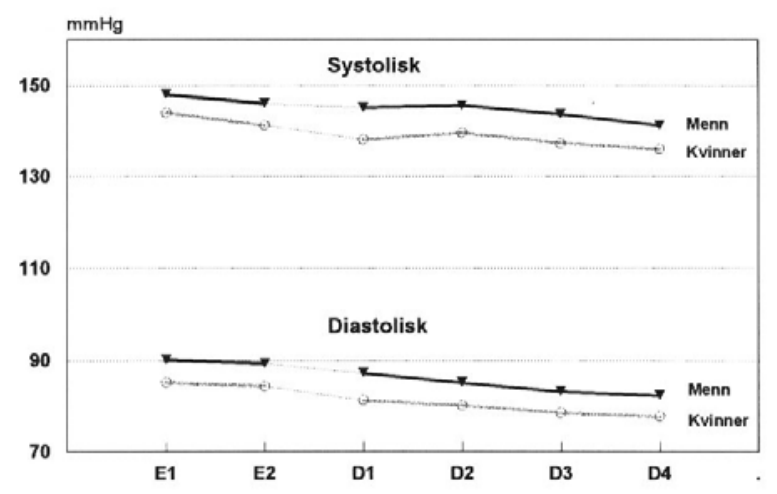

Figur 1. Blodtrykk målt først med Erka $(E)$, så med Dinamap (D). Menn og kvinner, 20-93 år $(\mathrm{n}=598)$.
For resten av studieperioden ble derfor de fremmøtte på grunnlag av fødselsdato randomisert til enten å bli målt først med Erka og siden med Dinamap (EDgruppen) eller til det motsatte; først å bli målt med Dinamap og siden med Erka (DE-gruppen). 4 individer viste seg å ha systolisk blodtrykk over $230 \mathrm{mmHg}$ da de ble målt med Erka. Disse ble ekskludert fra studien da den Dinamapmodellen vi brukte ikke kunne måle trykk over $230 \mathrm{mmHg}$. 522 individer fra 20-88 år av begge kjønn ble målt i den randomiserte designen. Analysen omfatter bare disse individene.

\section{RESULTATER}

\section{Generell brukbarhet}

Når personer med Erkamålt systolisk trykk over 230 mmHg var ekskludert, fikk $93,8 \%$ av de målte registrert et Dinamaptrykk ved første forsøk. 5,5\% fikk registrert trykk i annet forsøk og $0,7 \%$ i tredje fors $ø$. Man oppnådde å få målt blodtrykket med Dinamap hos alle. $95 \%$ av dem som hadde fått registrert en Dinamapmåling fikk også registrert 3 målinger til uten ommålinger. Hos $4,1 \%$ var en ommåling, hos $0,9 \%$ var to eller flere ommålinger nødvendig før man fikk registrert 4 Dinamaptrykk.

\section{Erka versus Dinamap}

Systolisk blodtrykk:

Figur 2 viser gjennomsnittlig systolisk blodtrykk for aldersgrupper og kjønn ved 2 Erkamålinger og 4 Dinamapmålinger. Man ser først det velkjente fenomenet at unge kvinner har lavere systolisk blodtrykk enn unge menn, i den eldste aldersgruppen er det omvendt. Man får inntrykk av at det er et sterkere fall over to Erkamålinger enn over to Dinamapmålinger. Dette er trolig et artefakt da det ikke er gitt at tiden mellom to Erkamålinger ble nøyaktig lik tiden mellom to Dinamapmålinger (slik det er plottet på figuren og slik intensjonene var). For begge kjønn ligger systolisk trykk målt med Erka og Dinamap gjennomsnittlig omtrent på samme nivå.

For den eldste aldersgruppen og spesielt hos kvinner ser man at første systoliske Dinamaptrykk tenderer til å være lavere enn annet Dinamaptrykk. Det skulle ikke være noen grunn til at eldre som måles med Dinamap skulle ha en slik abnorm blodtrykksutvikling over de fire Dinamapmålingene. Som for Erkamålingene forventes det at det skal være et avtagende fall i blodtrykk fra første Dinamapmåling av. For å sannsynliggjøre at et abnormt lavt systolisk trykk ved første Dinamapmåling ikke var et rent aldersfenomen, ble kvinner og menn slått sammen og materialet inndelt $\mathrm{i}$ kvintiler på grunnlag av gjennomsnittet av de to Erkamålingene (figur 3). Vi ser at gruppen med høyest systolisk trykk (Q5) viser en tydelig økning fra D1 til D2. For Q4 er det også en knekk på Dinamapkurven mens blodtrykket faller "forskriftsmessig" fra D1 til D4 for 
Tabell 1. Blodtrykksmansjetter brukt for Erka og Dinamap.

\begin{tabular}{lccccr}
\hline & Arm & Cuff & Ballong & Type & $\%$ \\
\hline Erka & Alle & $15 \mathrm{~cm} \times 55 \mathrm{~cm}$ & $14 \mathrm{~cm} \times 22 \mathrm{~cm}$ & Tycos & 100 \\
Dinamap & $\leq 24 \mathrm{~cm}$ & $12 \mathrm{~cm} \times 37 \mathrm{~cm}$ & $10 \mathrm{~cm} \times 22 \mathrm{~cm}$ & Criticon & 3 \\
& $25-35 \mathrm{~cm}$ & $15 \mathrm{~cm} \times 50 \mathrm{~cm}$ & $13 \mathrm{~cm} \times 25 \mathrm{~cm}$ & $"$ & 93 \\
& $\geq 36 \mathrm{~cm}$ & $17 \mathrm{~cm} \times 60 \mathrm{~cm}$ & $15 \mathrm{~cm} \times 33 \mathrm{~cm}$ & $"$ & 4 \\
\hline
\end{tabular}
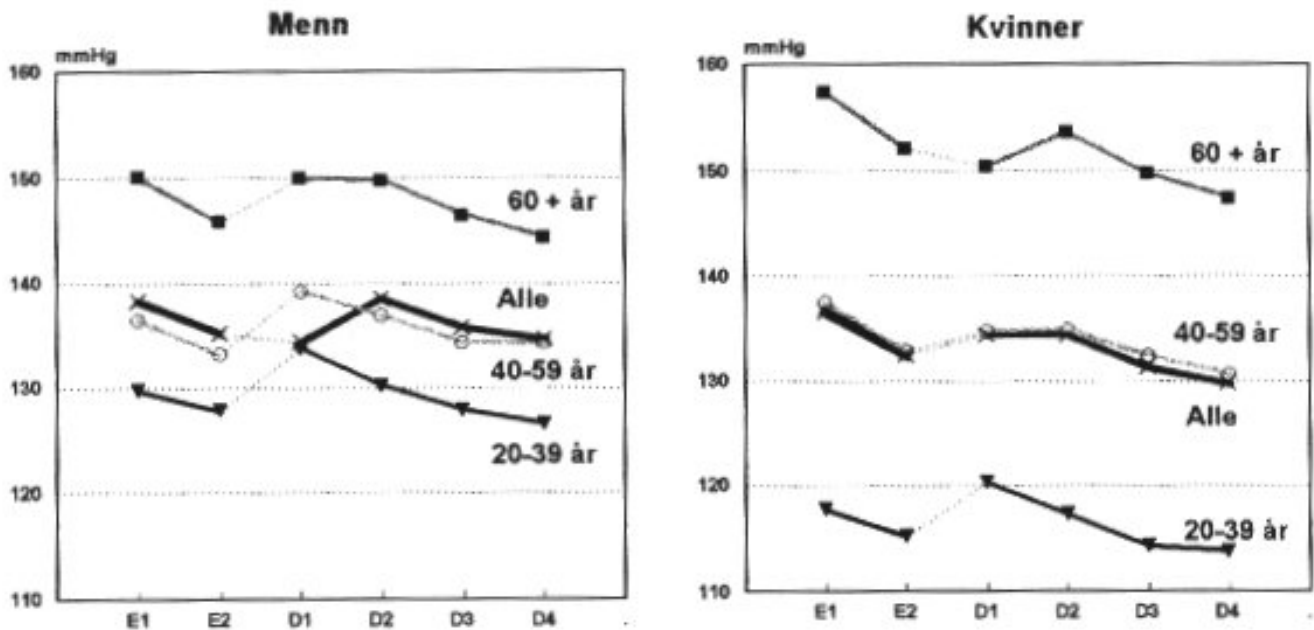

Figur 2. Systolisk blodtrykk (gjennomsnitt) målt med Erka (E) og Dinamap (D) i randomisert rekkefølge, for alder og kjønn.

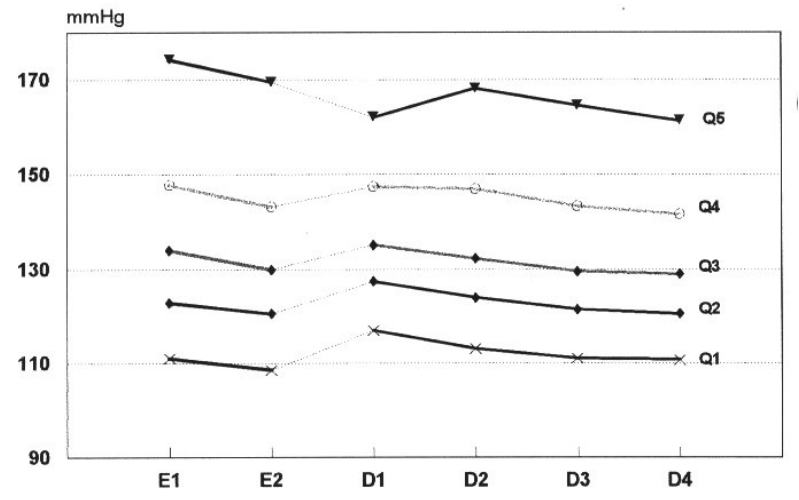

Figur 3. Systolisk blodtrykk målt med Erka (E) og Dinamap (D) i randomisert rekkefølge pr. kvintiler av gjennomsnitt av Erkamålingene (1/2 (Esys $1+$ Esys $\left.\left._{2}\right)\right)$.

Q3-Q1. Etter all sannsynlighet er den for lave systoliske D1 målingen ved høye blodtrykk en systematisk feilmåling som er forårsaket av den måten Dinamap arbeider på. Dinamap er programmert til å pumpe opp trykket første gang til $170 \mathrm{mmHg}$. Dersom den ikke er i stand til å registrere de endringer i oscillometriutslagene som indikerer det systoliske trykket, slipper den ut trykket og begynner en ny oppblåsning som nå går til $200 \mathrm{mmHg}$. Man har inntrykk av at det her er en svakhet i programmeringen av denne Dinamapmodellen. Ved annen måling vil Dinamap i de aller fleste tilfellene ha bestemt seg for blodtrykksnivået og komme til et rimelig trykk, men ved trykk nær 230 mmHg vil selv måling 2 kunne bli for lav. Er systolisk trykk høyere enn $230 \mathrm{mmHg}$ vil det ikke fremkomme noe trykk selv etter flere oppblåsninger, og det vil heller ikke fremkomme MAP eller hjertefrekvens. På grunn av det nevnte problemet med systematisk feilmåling av første systoliske Dinamaptrykk brukes i det følgende Dinamaptrykk 2 og 3 (D2, D3) både for systolisk og diastolisk trykk.

Sammenligner man blodtrykksnivået for E1-E2 med nivået for D2-D3 ser man av figur 2 og figur 3 at gjennomsnittlig systolisk trykk i en befolkning vil bli ganske likt enten det måles med Erka eller med Dinamap. 

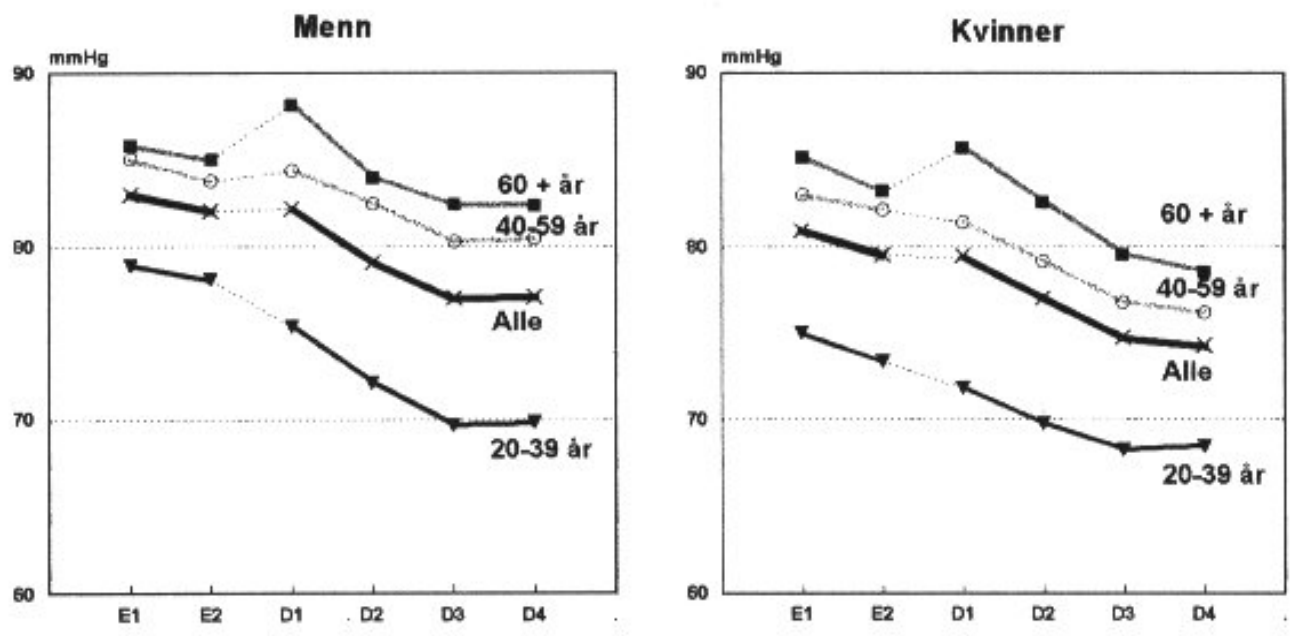

Figur 4. Diastolisk blodtrykk (gjennomsnitt) målt med Erka (E) og Dinamap (D) i randomisert rekkefølge, for alder og kjønn.

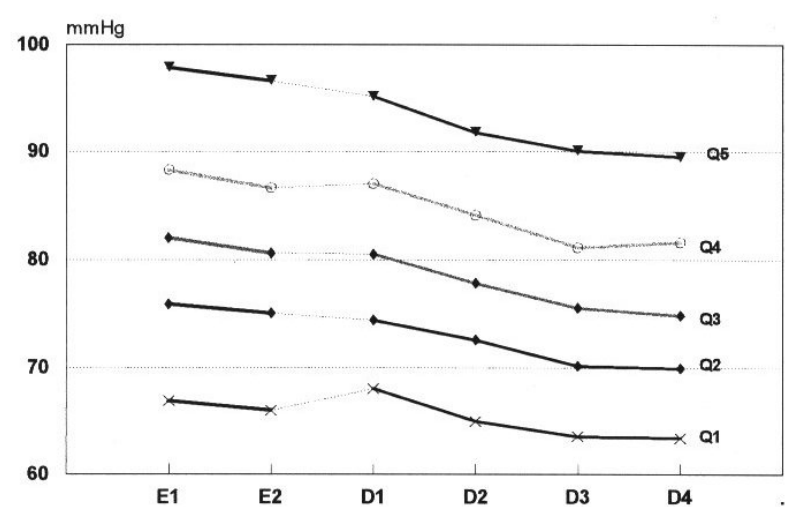

Figur 5. Diastolisk blodtrykk målt med Erka (E) og Dinamap (D) i randomisert rekkefølge pr. kvintiler av gjennomsnitt av Erkamålingene (1/2 (Edia $\left.\left.1+\mathrm{Edia}_{2}\right)\right)$.

\section{Diastolisk blodtrykk:}

Figur 4 viser at det gjennomsnittlige diastoliske trykket målt med Dinamap (når en ser bort fra D1 for aldersgruppen 60+) ligger noen $\mathrm{mmHg}$ lavere enn trykket målt med Erka, for begge kjønn. I figur 5, hvor materialet er delt i kvintiler på grunnlag av gjennomsnittet av Erkamålingene, ser en at Dinamap har tendens til å undermåle det diastoliske blodtrykket på alle disse nivåene.

\section{Intra-apparatforskjeller}

Figur 6 viser forskjell i trykk fra første til andre Erkamåling (fra E1 til E2) og fra andre til tredje Dinamapmåling (fra D2 til D3). For systolisk trykk er det gjennomsnittlige fallet (systematisk fall) over to målinger noe større for Erka enn for Dinamap (dette kan som nevnt være et artefakt pga. litt forskjellig tid mellom to målinger). Spredningen omkring dette gjennomsnittet er litt større for Dinamap enn for Erka. For diastolisk trykk er det gjennomsnittlige fallet $1 \mathrm{~mm}$ mindre for Erka enn for Dinamap, mens spredningen omkring gjennomsnittet fortsatt er større for Dinamap enn for Erka.

Disse variasjonene $\mathrm{i}$ to nær påfølgende målinger med samme teknikk, kan både skyldes variasjoner i det underliggende blodtrykket og målefeil. Man må tydeligvis for begge målemetoder regne med at det målte blodtrykket kan svinge omkring et individuelt gjennomsnitt med utslag på både $5 \mathrm{og} 10 \mathrm{mmHg}$.

En viktig grunn til en epidemiologisk interesse for Dinamap når en allerede har en god manuell metode, er at man har vært klar over at manuelle målere alltid vil være biased. Når en måler har målt ett trykk hos et individ vil måleren ha forventninger til det neste trykket. Dette gjelder både diastolisk trykk når en har målt systolisk trykk først, og både systolisk og diastolisk trykk når en kjenner disse trykkene og måler ved en senere anledning. Figur 6 demonstrerer trolig dette ved at spredningen omkring middelverdien er mindre for både systolisk og diastolisk trykk målt med Erka enn når de er målt med Dinamap. Fra tabell 2 vil en kunne se at det er en høyere korrelasjon mellom to påfølgende systoliske og mellom to påfølgende diastoliske trykk når de er målt med Erka enn når de er målt med Dinamap. Dinamapmålingene må regnes å være "unbiased" og skulle derfor gi et mer korrekt utrykk for disse assosiasjonene enn Erkamålingene. Tabell 2 viser imidlertid også at korrelasjonen mellom systolisk og diastolisk trykk ved samme måling er høyere for Dinamap enn for Erka.

\section{Måling på forskjellige blodtrykksnivåer}

Det er en kjent sak at når man måler en spesielt høy verdi ved en første måling er det i gjennomsnitt en tendens til at den neste målingen vil ligge litt lavere. Spesielt lave verdier ved en førstemåling vil i 

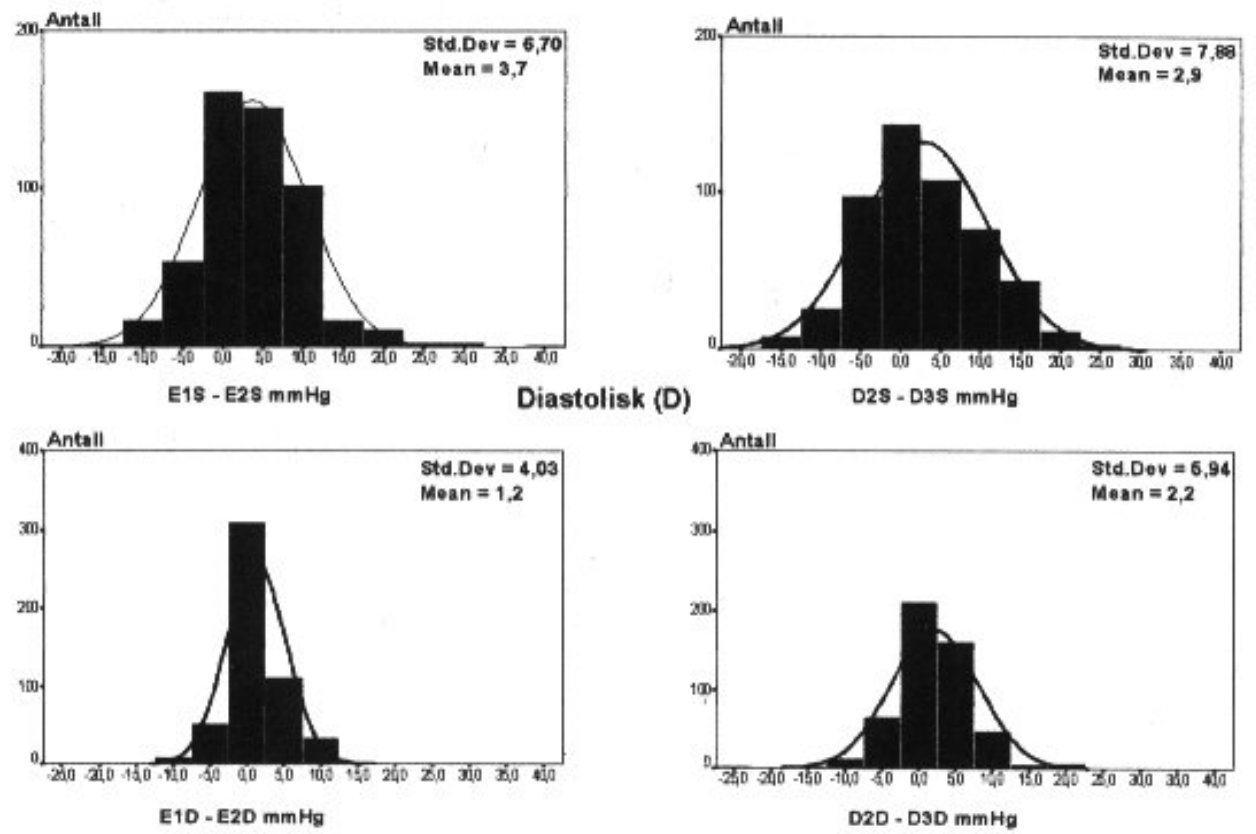

Figur 6. Forskjell i trykk fra E1 til E2 og fra D2 til D3 for systolisk og diastolisk trykk $(\mathrm{n}=524)$.

Tabell 2. Parvise korrelasjonskoeffisienter (Pearson's) for variable som inngår i analysen.

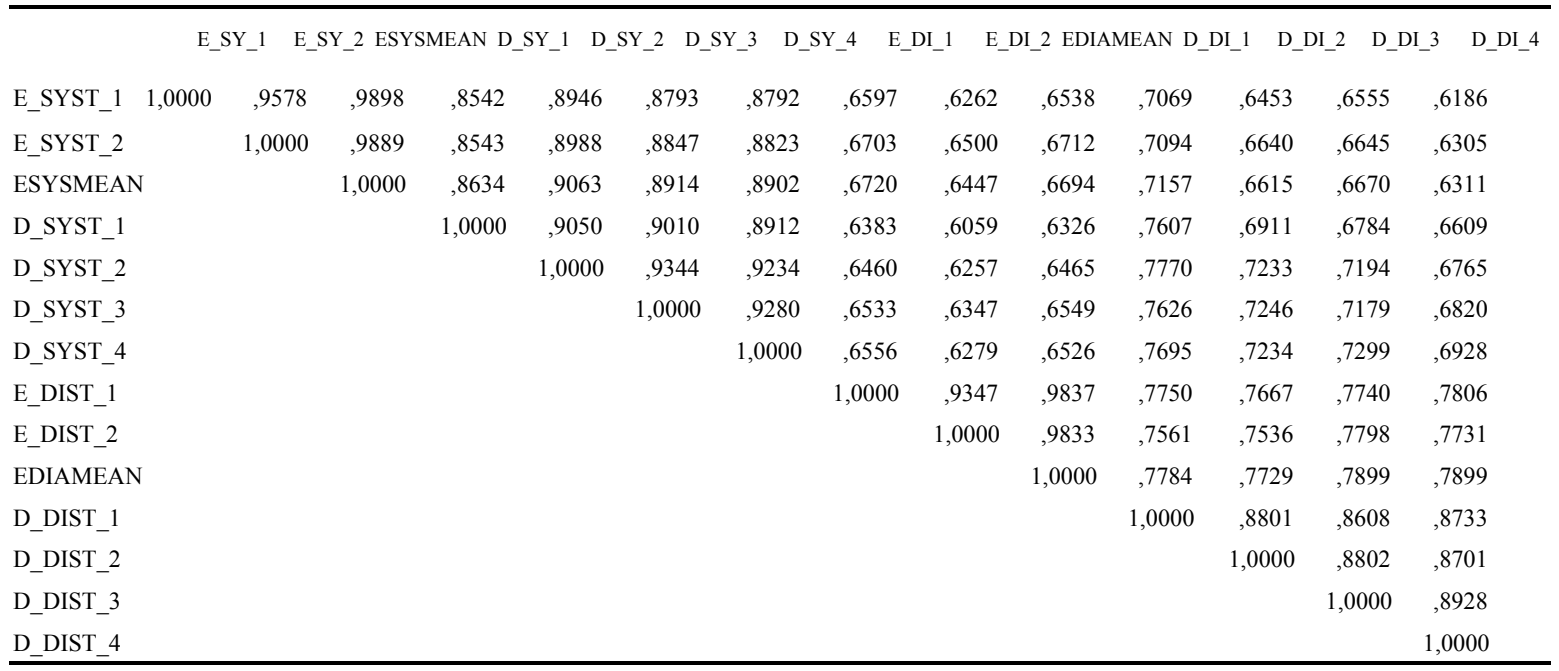

gjennomsnitt ligge litt høyere når målingen repeteres (regresjon mot middelverdien). Det materialet vi her analyserer på er randomisert til enten å være målt først med Erka eller å være målt først med Dinamap. Den punktskyen man ser plottet i figurene 7 og 8 består egentlig av to skyer. ED gruppen vil tendere til at høye verdier med Erka vil ligge litt lavere med Dinamap, lave verdier med Erka vil tendere til å ligge litt høyere med Dinamap. Regresjon mot middelverdi-effekten vil for ED gruppen føre til at regresjonslinjen vil bli litt steilere enn den ville ha vært uten regresjon mot middelverdi, og en justering av regresjonskoeffisienten for regresjon mot middelverdi ville gjøre regresjonslinjen flatere i dette plottet. For DE gruppen vil punktskyen, slik aksene er ordnet i dette plottet, på grunn av regresjon mot middelverdien egentlig ligge litt for flatt, og en justering for regresjon mot middelverdien ville gi en litt brattere regresjonslinje. Regresjonslinjen for skyen som helhet vil grovt sett måtte halvere vinkelen mellom regresjonslinjene for ED og DE. De regresjonslinjene en ser i plottene bør derfor være godt kompensert for regresjon mot middelverdi i dette 


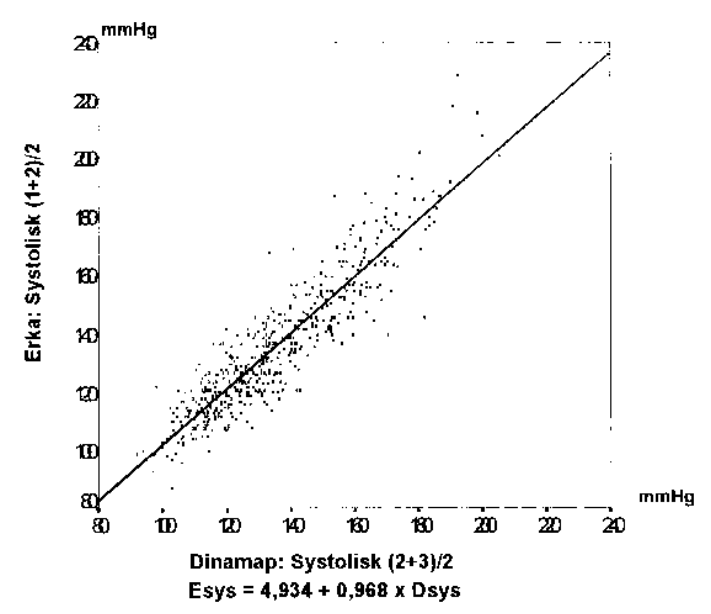

Figur 7. Plott av gjennomsnitt av 2 Dinamap-målinger mot gjennomsnitt av 2 Erka-målinger for systolisk blodtrykk, med tilsvarende regresjonslinje.

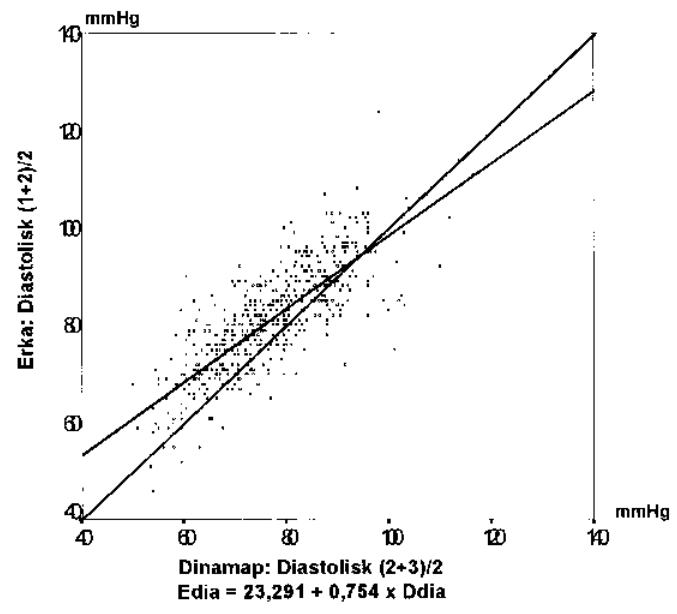

Figur 8. Plott av gjennomsnitt av 2 Dinamap-målinger mot gjennomsnitt av 2 Erka-målinger for diastolisk blodtrykk, med tilsvarende regresjonslinje.

Tabell 3. Samsvar mellom Erka 1 eller Erka 2 og forskjellige Dinamap målinger, uttrykt som regresjoner.

\begin{tabular}{|c|c|c|c|c|}
\hline \multirow[t]{3}{*}{ Erka: } & Syst. 1 & Dinamap & Syst. 2 & $\mathrm{ES} 1=8,353+0,946 \times \mathrm{DS} 2$ \\
\hline & & $"$ & & $\mathrm{ES} 1=9,123+0,961 \times \mathrm{DS} 3$ \\
\hline & & $"$ & " 4 & $\mathrm{ES} 1=8,067+0,979 \times \mathrm{DS} 4$ \\
\hline \multirow[t]{3}{*}{ Erka: } & Syst. 2 & Dinamap & Syst. 2 & $\mathrm{ES} 2=9,428+0,911 \times \mathrm{DS} 2$ \\
\hline & & $"$ & & $\mathrm{ES} 2=10,009+0,927 \times \mathrm{DS} 3$ \\
\hline & & $"$ & " 4 & $\mathrm{ES} 2=9,296+0,942 \times \mathrm{DS} 4$ \\
\hline \multirow[t]{4}{*}{ Erka: } & Diast. 1 & Dinamap & Diast. 1 & $\mathrm{ED} 1=25,541+0,698 \times \mathrm{DD} 1$ \\
\hline & & $"$ & " 2 & $\mathrm{ED} 1=27,537+0,697 \times \mathrm{DD} 2$ \\
\hline & & $"$ & " 3 & $\mathrm{ED} 1=26,265+0,734 \times \mathrm{DD} 3$ \\
\hline & & $"$ & " 4 & $\mathrm{ED} 1=25,434+0,747 \times \mathrm{DD} 4$ \\
\hline \multirow[t]{4}{*}{ Erka: } & Diast. 2 & Dinamap & Diast. 1 & $\mathrm{ED} 2=26,343+0,673 \times \mathrm{DD} 1$ \\
\hline & & " & $" 2$ & $\mathrm{ED} 2=27,872+0,677 \times \mathrm{DD} 2$ \\
\hline & & $"$ & " 3 & $\mathrm{ED} 2=25,281+0,731 \times \mathrm{DD} 3$ \\
\hline & & $"$ & " 4 & $\mathrm{ED} 2=25,407+0,731 \times \mathrm{DD} 4$ \\
\hline
\end{tabular}

materialet. Figur 7 viser plott av Dinamap systolisk $(2+3) / 2$ på Erka systolisk $(1+2) / 2$ med tilhørende formel for den lineære regresjonslinjen. Regresjonslinjen for denne punktskyen krysser identitetslinjen ved $154,3 \mathrm{mmHg}$, som man kan regne seg til fra formelen. Linjen går videre gjennom gjennomsnittet for disse variablene 135,6 og 134,9 mmHg for hhv. Erka og Dinamap. Konsekvensen av dette er at Dinamap vil undermåle systolisk blodtrykk avhengig av nivået opp til $154 \mathrm{mmHg}$, over dette nivået tenderer Dinamap til å overmåle. Da regresjonskoeffisienten avviker meget lite fra 1 vil disse måleforskjellene bli små. Ved Dinamap systolisk blodtrykk f.eks. $200 \mathrm{mmHg}$, vil Erka teoretisk måle 198,5 mmHg. Regresjonslinjen avviker så lite fra identitetslinjen at "the line of identity" ikke er tegnet.

Et befolkningsgjennomsnitt vil etter dette bli målt en antydning lavere med Dinamap enn med Erka da middelverdien for de fleste normalpopulasjoner ligger under $154 \mathrm{mmHg}$. Figur 8 viser tilsvarende plott av diastolisk blodtrykk. Det er tydelig at punktskyen og den tilsvarende regresjonslinjen går adskillig flatere enn identitetslinjen. Regresjonslinjen krysser identitetslinjen ved $94,7 \mathrm{mmHg}$. Det betyr at Dinamap undermåler i økende grad når det diastoliske blodtrykket ligger under $95 \mathrm{mmHg}$. Et populasjonsgjennomsnitt målt med Dinamap vil ligge betydelig lavere enn målt med Erka. Er populasjonsgjennomsnittet 80 mmHg målt med Erka vil det teoretisk bli målt til 75 mmHg med Dinamap. Et blodtrykk på 110 målt med Erka vil teoretisk bli målt til $115 \mathrm{mmHg}$ med Dinamap.

Formlene for regresjonslinjene i figurene 7 og 8 vil med rimelig sikkerhet kunne brukes til omregning fra Dinamap til Erka, gitt at man tar utgangspunkt i gjennomsnitt av to Erkamålinger [(E1+E2)/2] og gjennomsnitt av 2 Dinamapmålinger [(D2+D3)/2]. Tabell 3 viser formler for regresjonslinjer for andre konstellasjoner av Dinamap og Erkamål. Rent formelt viser tabell 3 regresjonslinjer for "Dinamap mot Erka" eller $\mathrm{X}$ mot Y. Selv om det ikke blir store forskjellen, vil regresjonslinjene for "Erka mot Dinamap" eller Y mot X være litt forskjellig fra $\mathrm{X}$ mot $\mathrm{Y}$ og er her ikke oppgitt.

\section{Apparatforskjell og nivå}

Figur 9 og figur 10 viser plott av måleforskjellen mellom Erka og Dinamap mot gjennomsnittet av målingene, for systolisk og diastolisk trykk. De horisontale linjene representerer gjennomsnittet for differansen Erka-Dinamap, de skrå linjene representerer den lineære regresjonslinjen for plottet.

For systolisk blodtrykk (figur 9) er det tydelig at gjennomsnittet av differansen Erka minus Dinamap er så godt som null. Regresjonskoeffisienten er også meget liten hvilket betyr at forskjellen mellom Erka og Dinamap endrer seg lite med blodtrykksnivået. Ved å fjerne noen få "outliers" vil regresjonskoeffisienten bli nesten null. 


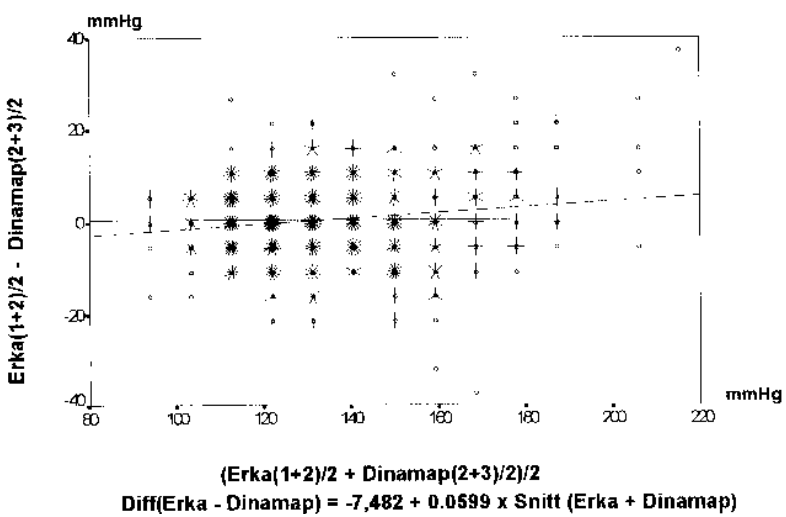

Figur 9. Differansen mellom systolisk blodtrykk målt med Erka og Dinamap plottet mot gjennomsnittet av de samme målingene.

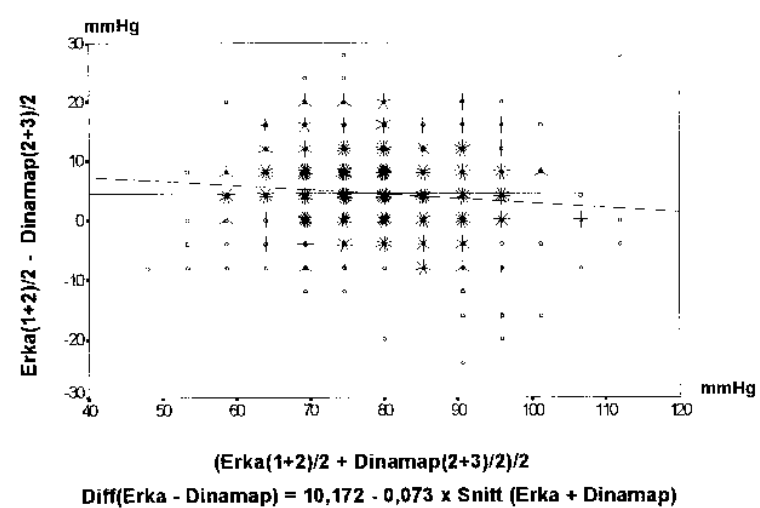

Figur 10. Differansen mellom diastolisk blodtrykk målt med Erka og Dinamap plottet mot gjennomsnittet av de samme målingene.

For diastolisk blodtrykk (figur 10) ser en som vist før at Erka i gjennomsnitt måler noen $\mathrm{mm}$ høyere enn Dinamap. Regresjonskoeffisienten er liten, men negativ, slik at Erkas tendens til å overmåle i forhold til Dinamap avtar med nivået. Regresjonslinjen holder seg i hele plottet over null slik at Dinamap vil undermåle i forhold til Erka for hele det blodtrykksområde vi har data for. Fra formelen for regresjonslinjen kan en regne seg til at Dinamap (vurdert på denne måten) vil tendere til å overmåle når diastoletrykket er høyere enn $139 \mathrm{mmHg}$.

\section{HVA SIER LITTERATUREN?}

Det har lenge vært klart at måling med vanlig kvikksølvmanometer byr på en del problemer, ikke minst når det gjelder målekriterier (når begynner egentlig Korotkoff lydene, når er de egentlig slutt?). Forskjel- lige varianter av kvikksølvmetoden, som Hawksley random zero og London School of Hygiene manometre, har fjernet noen av problemene, men har medført betydelige merkostnader i tid og penger.

Det er etter hvert kommet mange automatmålere på markedet. Blant de første som tok i bruk oscillometri var Dinamap. Selv om Dinamap har vært i bruk i klinikk og vitenskap i flere varianter i mer enn 10 år, er det sparsomt med opplysninger i litteraturen om Dinamap som epidemiologisk instrument. Etter å ha søkt i litteraturen fra 1992 til 1997 er konklusjonen at noen sammenligning av Erka og Dinamap 845XT synes å mangle. Som bifunn er det i små kliniske studier på barn, voksne, og på dyr, antydet at Dinamap synes å ha en tendens til å undermåle diastolisk trykk mens det systoliske trykket synes å svare til blodtrykk målt med kvikksølvmetoder.

\section{KONKLUSJON}

Dinamap 845XT (CritiKon) er lite sensitiv for de rytme- og pulsvariasjoner en til vanlig har $\mathrm{i}$ en bred befolkningsgruppe som møter til screening. Dinamap vil i de fleste tilfellene komme fram til rimelige resultater, men en vil i noen få tilfeller måtte gjøre flere måleforsøk.

Ved høye systoliske trykk vil første Dinamaptrykk systematisk ligge for lavt i forhold til senere Dinamaptrykk. Det er derfor å anbefale at en for systolisk trykk anvender måling 2 eller 3 eller et gjennomsnitt av disse. For diastolisk trykk er første måling like pålitelig som senere målinger.

Gjennomsnittsblodtrykket $\mathrm{i}$ en vanlig befolkning vil for systolisk trykk bli målt meget likt enten det er målt på "Gamlemåten" eller med Dinamap. Følger man systolisk blodtrykk over tid i Norge, og det har vært en overgang fra Erka til Dinamap i perioden, er det ikke å forvente at det kan sees noen "knekk". For diastolisk trykk måler Dinamap systematisk lavere (avhengig av nivået) enn Erka. Det er derfor å vente at tidstrenden for diastolisk blodtrykk vil vise en knekk der en eventuelt går over til Dinamapmålte trykk.

Dinamap må regnes å være et bedre epidemiologisk instrument enn Erka da en unngår lesefeil som "digit preference" og parallaksefeil, og man unngår Erkamålerens tendens til å være biased. Det er rimelig å anta at også andre feil som skyldes menneskelig svikt, unngås. Dinamap er arbeidsbesparende for måleren. Dinamap leverer MAP og HR i tillegg til systolisk og diastolisk trykk, noe som ser ut til å være av økende epidemiologisk interesse. Om man i klinisk arbeid bruker Erka eller Dinamap, er av mindre betydning enn at man til enhver tid arbeider med et veljustert apparat, og at man samvittighetsfullt følger de regler som er anvist for måling. 